\title{
Reconstruction of Curcuma aeruginosa Secondary Metabolite Biosynthetic Pathway using Omics Data
}

(Pembinaan Semula Tapak Jalan Biosintetik Metabolit Sekunder Curcuma aeruginosa Menggunakan Data Omiks)

\author{
NURUL-SYAFIKA MOHAMAD-FAUZI, RABIATUL-ADAWIAH ZAINAL-ABIDIN, MOHD WAZNUL ADLY ZAIDAN, \\ SANIMAH SIMOH, ALIZAH ZAINAL \& ZETI-AZURA MOHAMED-HUSSEIN*
}

\begin{abstract}
Curcuma aeruginosa or temu hitam is herbaceous plant with high therapeutic values in its rhizome that is widely used in traditional medicine. However, molecular studies on the secondary metabolite biosynthetic pathway of $\mathrm{C}$. aeruginosa is still limited. Hence, the aim of this study was to explore and reconstruct the secondary metabolite biosynthetic pathway of $\mathrm{C}$. aeruginosa rhizome by integrating the metabolite profiling and transcriptomic data. A total of 81 metabolites were identified in the rhizome of $\mathrm{C}$. aeruginosa; amongst others are curzerene and $\beta$-Cubebene which are potent antioxidants. A total of 28,225 unigene were obtained from the transcriptomic sequencing of $\mathrm{C}$. aeruginosa rhizome and analysed to identify potential genes associated with the biosynthesis of its metabolites. Of these, 43 unigenes were identified and mapped onto five sub-pathways; i.e. carotenoid biosynthetic pathway, diterpenoid biosynthetic pathway, monoterpenoid biosynthetic pathway, terpenoid and steroid biosynthetic pathway, and sesquiterpenoid and triterpenoid biosynthetic pathway. This study demonstrated a systematic bioinformatic approach to reconstruct a metabolic pathway in the rhizome of $\mathrm{C}$. aeruginosa using bioinformatic approach .
\end{abstract}

Keywords: Data integration; metabolic pathway; metabolomics; pathway reconstruction; transcriptomic

\section{ABSTRAK}

Curcuma aeruginosa atau temu hitam merupakan sejenis tumbuhan herba yang mempunyai nilai terapeutik tinggi pada bahagian rizomnya dan telah digunakan secara meluas dalam perubatan tradisi. Namun begitu, masih banyak yang belum diketahui tentang penghasilan metabolit sekunder di dalam C. aeruginosa. Kajian ini dijalankan untuk membina semula tapak jalan biosintesis $\mathrm{C}$. aeruginosa dengan menggunakan data pemprofilan metabolit sekunder dan transkriptomik. Sebanyak 81 metabolit telah dikenal pasti di dalam rizom seperti curzerene dan $\beta$-Cubebene yang berfungsi sebagai anti-oksidan. Sejumlah 28,225 unigen yang terhasil daripada penjujukan transkriptomik rizom C. aeruginosa telah dianalisis untuk mencari dan mengenal pasti sebarang gen yang terlibat di dalam penghasilan metabolit di dalam rizom $\mathrm{C}$. aeruginosa. Terdapat 43 unigen telah dikenal pasti terlibat di dalam lima tapak jalan biosintetik utama iaitu biosintesis karotenoid, biosintesis diterpenoid, biosintesis monoterpenoid, biosintesis terpenoid dan steroid serta biosintesis sesquiterpenoid dan triterpenoid. Kajian ini juga memfokuskan kepada strategi pembinaan semula tapak jalan biosintetik yang terlibat dalam rizom C. aeruginosa dengan menggunakan pendekatan bioinformatik.

Kata kunci: Integrasi data; metabolomik; pembinaan semula tapak jalan; tapak jalan metabolik; transkriptomik

\section{INTRODUCTION}

Curcuma aeruginosa Roxb also known as temu hitam is an interesting aromatic blue rhizome belongs to Zingiberaceae family. This herb is popular in Asian countries and commonly found in the forests and river banks. It has been widely used in ethnomedicine as its rhizome has multiple therapeutic properties to cure various gastrointestinal disorders (Rajkumari \& Sanatombi et al. 2018) and rheumatic disease (Liu et al. 2013).

At present there is a limited knowledge on the $C$. aeruginosa molecular information hence it is essential to investigate the metabolites and their associated bioactive compounds which have significant therapeutic properties. This investigation was achieved through metabolite profiling technique using gas chromatography-mass spectrometer (GC-MS) or liquid chromatography-mass spectrometer (LC-MS). Kamazeri et al. (2012) used a gas chromatography-mass spectrometry (GC-MS) technique to elucidate the bioactive compounds with anti-microbial and food preservative properties and to identify possible compounds to be used as essential oils. Meanwhile Simoh and Zainal (2015) have conducted a phytochemistry profiling of $C$. aeruginosa rhizome using different solvent extractions and 81 metabolites have been identified. Knowledge on the metabolite profiling is important to gain insight on the phytochemical composition in the rhizome of $C$. aeruginosa and as well as enabling it to be registered as one of the potential health products. 
In addition to the metabolic profiles of $C$. aeruginosa rhizome, there were only 80 nucleotides and 30 protein sequences of $C$. aeruginosa were deposited in NCBI database (https://www.ncbi.nlm.nih.gov/gquery/?term=Curcuma+a eruginosa+) as of 20 March 2018. This limited genomic information has restricted the effort to the single-species metabolic pathway that can facilitate the understanding of biological mechanism involved in the rhizome of $C$. aeruginosa. Now the availability of metabolite profiles (Simoh \& Zainal 2015) and transcriptomic data (Zaidan et al. 2016) of C. aeruginosa rhizome have provided an opportunity to reconstruct its metabolic pathway by integrating both omics data in combination with the functional characterization of genes and metabolites in search for the interesting bioactive compounds. Metabolic pathway reconstruction offers an essential step in deciphering the macromolecular relationship towards understanding the biological mechanisms involved in specific traits (Kitano 2002). Moreover, it serves as a platform to visualize the omic components involved in the biological and cellular processes (Francke et al. 2005). Therefore, findings from the reconstruction of metabolic pathway will serve as a valuable resource to facilitate the research on traditional herbs and development of natural products for therapeutic needs.

In this study, the unigenes and metabolites data were integrated and mapped onto the pathway template as part of reconstructing the species-specific pathways in $C$. aeruginosa rhizome. Five major biosynthetic pathways in rhizome of $C$. aeruginosa were elucidated; i.e., carotenoid, diterpenoid, monoterpenoid, terpenoids and steroids and sesquiterpenoids and triterpenoids biosynthetic pathways. The findings from this study will serve as a step forward in unravelling the major genes behind important biosynthetic pathway for better manipulation in the development of natural products for pharmaceutical applications.

\section{MATERIALS AND METHODS}

\section{DATA SOURCES}

Simoh and Zainal (2015) provided the C. aeruginosa rhizome metabolomics data set whilst unigenes data was obtained from the transcriptomic analysis performed by Zaidan et al. (2016). Metabolomics data set consisted of compound descriptions such as compound name, molecular formula, molecular weight, retention time and peak area. Unigene data set comprised of descriptions of unigenes name, identifier, annotation descriptions, annotation identifier and KEGG identifier in tab-delimited format.

\section{CLASSIFICATION OF METABOLITES PROFILING}

Metabolites profiles were classified into primary and secondary metabolites by comparing the information from CheBI (Hastings et al. 2013), KEGG (Kanehisa et al. 2016) and PlantCyc (Schlapfer et al. 2017).

\section{MAPPING OF GENES AND METABOLITES}

The mapping of gene identifiers and metabolites was performed using data mined from CheBI, PlantCyc (Schlapfer et al. 2017), Medicinal Plant Metabolomics Resources (Wurtele et al. 2012), STRING (Szklarczyk et al. 2017), BioGRID database (Chatr-Aryamontri et al. 2017), UniProt database (Bateman et al. 2015) and TAIR (Berardini et al. 2015) databases.

\section{RECONSTRUCTION OF METABOLITE BIOSYNTHETIC PATHWAY}

The biosynthetic pathways of C.aeruginosa rhizome were constructed by mapping the relevant/related genes and metabolites data onto relevant skeleton pathways obtained from KEGG (Kanehisa et al. 2016) and were used as a reference model for the reconstruction of $C$. aeruginosa rhizome metabolite biosynthetic pathways.

\section{RESULTS AND DISCUSSION}

\section{CLASSIFICATION OF METABOLITE DATA}

A total of 81 metabolites were identified from the metabolite profiles of C. aeruginosa rhizome (Simoh \& Zainal 2015). Of these, four of them are primary metabolites whereas 77 are secondary metabolites (Table 1). The primary metabolites are 8,9 b- Dimethyl -4a, 9b-dihydrodibenzol [b,d] furan-3 (4H)-one, D-Fructose, 1,3,4,5,6-pentakis-O- (TMS)-, O-methyloxime, D-Glucose, 2,3,4,5,6-pentakis-O(TMS)$\mathrm{O}$-methyloxime and $\alpha$-D Glucopyranoside, $2,3,4,5,6$ tetrakis-O-(TMS)- $\beta$-D-fructofuranosyl 2,3,4,6-tetrakis-O(TMS). Primary metabolites such as carbohydrate, lipid and protein are involved in plant growth and metabolism process (Sanchez \& Demain 2008) whereas secondary metabolites such as alkaloid, steroid, tannins, and phenolic are usually involved in plant defence mechanism and are known to have antioxidant, anti-cancer and antiinflammatory properties (Filippis 2016); making them as potential materials in the development of functional food and pharmaceutical products (Cameron et al. 2005).

\section{IDENTIFICATION OF SECONDARY \\ METABOLITE BIOSYNTHETIC PATHWAY IN THE RHIZOME OF C. AERUGINOSA}

Further investigation was performed on the 77 identified metabolites to elucidate the biosynthetic pathways in the rhizome of $C$. aeruginosa and 72 pathways were identified. However, only five major biosynthetic pathways were highlighted in this study with its potential in pharmaceutical application (Rajkumari \& Sanatombi 2018); i.e. terpenoid and steroid biosynthetic pathway, carotenoid biosynthetic pathway, diterpenoid biosynthetic pathway, monoterpenoid and sesquiterpenoid biosynthetic pathway and triterpenoid biosynthetic pathway (Table 1).

Monoterpenoid and terpenoid are bioactive compounds involved in pharmacological activities with many pharmaceutical applications (Sawai \& Saito 2011; Singh 
TABLE 1 . Summary of five major biosynthetic pathways in C. aeuroginosa rhizome

\begin{tabular}{|c|c|c|}
\hline KEGG Identifier & Biosynthetic Pathway & List of metabolites \\
\hline map01062 & Terpenoid \& steroid biosynthetic pathway & $\begin{array}{l}\text { 3-Carene } \\
\text { Camphene } \\
\text { Borneol } \\
\alpha \text {-Terpineol } \\
\beta \text {-Sitosterol } \\
\text { Butanedioic acid, [(TMS) oxyl-, bis (TMS) ester } \\
\text { Citric acid, ethyl ester, tri-TMS } \\
\text { Isocitric acid (TMS) } \\
\text { Borneol-TMS ether } \\
\text { Germacra-1(10),4-diene-12-oic acid } 6 \text { alpha } \\
\text { hydroxy gamma lactone }\end{array}$ \\
\hline map00906 & Carotenoid biosynthetic pathway & Tetracosane \\
\hline map00904 & Diterpenoid biosynthetic pathway & Anthiaergostan-5,7,9,22-tetraen-14-ol-15-one \\
\hline map00902 & Monoterpenoid biosynthetic pathway & $\begin{array}{l}\text { Camphene } \\
\text { 2-Thujene } \\
\beta \text {-Pinene } \\
\text { Cineole (Eucalyptol) } \\
\text { Borneol } \\
\alpha \text {-Terpineol } \\
8,9 \text { b-Dimethyl-4a,9b-dihydrodibenzol[b,d] } \\
\text { furan-3(4H)-one } \\
\text { 3-methyl cyclopentane-1-yl-TMS ether }\end{array}$ \\
\hline map00909 & Sesquiterpenoid \& triterpenoid & $\begin{array}{l}\text { Caryophyllene } \\
\text { Germacrene B } \\
\text { Z- } \alpha \text {-farnesene } \\
\text { Germacrone } \\
\text { Cycloisolongifolene, 8,9-dehydro-9-formyl } \\
\text { Germacra-1(10),4-diene-12-oic acid } 6 \text { alpha } \\
\text { hydroxy gamma lactone }\end{array}$ \\
\hline
\end{tabular}

\& Sharma 2015). Sesquiterpenoid and triterpenoid are biosynthesized via MEP pathway whereas monoterpenoid and diterpenoid are biosynthesized via MEP pathway (Sawai \& Saito 2011). Meanwhile, carotenoid biosynthetic pathway contributes to the biosynthesis of orange pigmentation and a good source for vitamin A (Matsuba et al. 2015; Othman et al. 2014; Satoru \& Saito 2011).

\section{IDENTIFICATION}

At present, the whole genome of $C$. aeruginosa is still unavailable hence the transcriptomic data of $C$.aeruginosa rhizome (Zaidan et al. 2016) was used to identify the genes involved. 28, 225 unigenes were successfully assembled and annotated. The annotation of these unigenes provided valuable information in search for genes related to the production of metabolites with high therapeutic values. Each unigene consists of gene name, gene identifier, gene description as well as KEGG pathway identifier. Functional annotation of unigenes has allowed the classification of unigenes on their respective biosynthetic pathways by using the identifiers-mapping approach. It has been demonstrated that the mapping between identifiers is known as pathway-based integration and it has been employed to integrate the transcriptomic and metabolomics data in elucidating the metabolic biosynthetic pathways involved (Cavill et al. 2015).

Since the primary focus of this study is on the five major biosynthetic pathways, further analyses were conducted to investigate the gene encoding enzymes that involved in these biosynthetic pathways resulting to the identification of monoterpenoid, carotenoid, diterpenoid, and terpenoid and steroid pathways that were assigned to $128,67,43$ and six total number of unigenes, respectively and only one unigene was found in relation to the sesquiterpenoid and triterpenoid biosynthetic pathway (Figure 1).

As details on the genes and metabolites in the rhizome of Curcuma aeuroginosa are still unavailable in all biological databases, it has limit our effort to reconstruct the biosynthetic pathway. To overcome this issue, Arabidopsis thaliana was used as a reference and model to map the genes and metabolites of Curcuma aeuroginosa rhizome. The availability of the genomics and genetics information of A. thaliana has made it possible for the gene mapping identifier approach. By mapping the gene names from $C$. aeruginosa rhizome against TAIR database, 43 genes were successfully mapped to the reference gene and protein identifiers. A total of 32 genes were found to reside in the monoterpenoid biosynthetic pathway (Table 


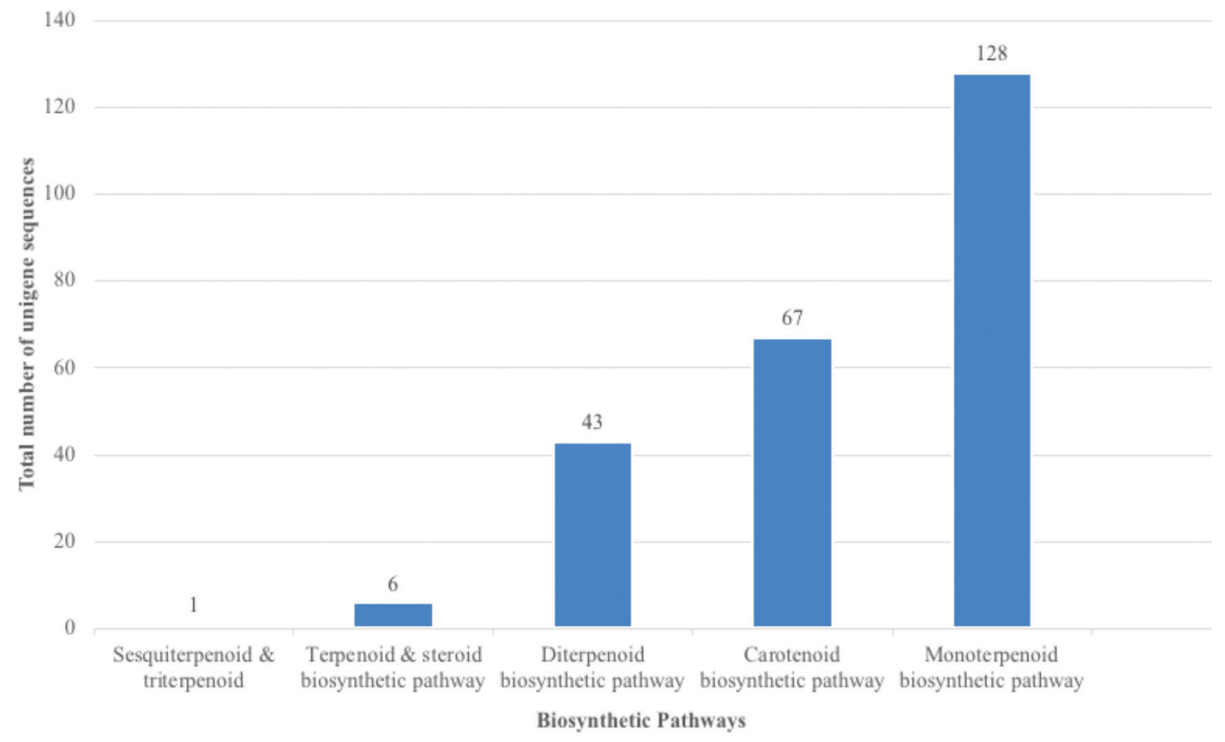

FIGURE 1. Distribution of unigenes in five major biosynthetic pathways of Curcuma aeuroginosa rhizome

2). Whilst, carotenoid, terpenoid and steroid, diterpenoid, sesquiterpenoid, and triterpenoid were associated with 5, 4, 5 and 2 genes of A. thaliana, respectively. This gene mapping analysis also showed that one gene can be involved in more than one biosynthetic pathway. This finding demonstrated that the 43 biosynthetic genes were mostly expressed in rhizome of $C$. aeruginosa. The interaction between molecules depends on the type of cell, condition, cell circulation phase, cell development, protein modification and binding cofactors (de Las Rivas \& Fontanillo 2010).

Genes in the rhizome of $C$. aeruginosa with significant medicinal value include squalene synthase (SQS), a key enzyme in catalysing the sesquiterpenoid and triterpenoid biosynthetic pathway (Abe et al. 1993). The importance of SQS in the sesquiterpenoid and triterpenoid biosynthetic pathway has been reported in the herbal medicine such as Bacopa monniera and Panax ginseng (Lee et al. 2004). The molecular cloning and characterization of SQS in B. monniera has allowed the researcher to investigate and understand the molecular mechanism involved as the level of triterpene accumulates in low concentrations (Vishwakarma et al. 2015). Hence, by understanding the molecular mechanism of SQS will help in genetic engineering the sesquiterpenoid and triterpenoid biosynthetic pathway for increasing the production of triterpene content towards pharmaceutical application.

\section{RECONSTRUCTION OF SECONDARY METABOLITE BIOSYNTHETIC PATHWAY OF C. AERUGINOSA}

A putative biosynthetic pathway of $C$. aeruginosa rhizome was reconstructed using gene-metabolite mapping approach (Figure 2) and consisted of five major secondary metabolite biosynthetic pathways. The reconstructed pathway comprised of five biosynthetic pathways, 31 metabolites and 43 genes encoding enzyme. However, more experimental work is needed to complete and validate this reconstructed biosynthetic pathway. For instance, the identification of enzyme commission (EC) number, reactions as well as gaps.

Currently, the biosynthetic pathway reconstruction in herbs are very limited thus much effort is needed to reconstruct the secondary metabolite biosynthetic pathways using omics data. This strategy has been used in the reconstruction of starch biosynthetic pathway in cassava (Saithong et al. 2013) and in the reconstruction of metabolic network of Setaria italica (de Oliveira Dal'Molin et al. 2016). Similar study has also indicated that it is essential to integrate the information from various metabolite pathway databases such as KEGG and BioCyc (Seaver et al. 2012) where this step has been successfully implemented in this study.

This study highlights major involvement of unigenes and metabolites in the terpenoid backbone biosynthetic pathway in the rhizome of $C$. aeruginosa. Five biosynthetic pathways; i.e., carotenoid, diterpenoid, monoterpenoid, terpenoids and steroids and sesquiterpenoids and triterpenoids biosynthetic pathways were derived from the terpenoid backbone biosynthetic pathway. Further study can be carried out on the establishment of these pathways for detailed understanding on their biological mechanisms towards the manipulation of high-value compounds for the industrial application ( $\mathrm{Li}$ et al. 2018) using synthetic biology approach. In addition, the reconstruction of biosynthetic pathway can also be established as a platform to assist the cloning and characterization of potential enzymes with various industrial, pharmaceutical and nutraceutical benefits (Saithong et al. 2013).

\section{CONCLUSION}

Integration of transcriptomic and metabolomics data has led to the identification of five major secondary metabolite 
TABLE 2. List of genes involved in selected metabolic biosynthetic pathways

\begin{tabular}{|c|c|c|c|}
\hline $\begin{array}{l}\text { Metabolic biosynthetic } \\
\text { pathway }\end{array}$ & $\begin{array}{l}\text { Gene identifier } \\
\text { C. aeruginosa }\end{array}$ & $\begin{array}{l}\text { Gene identifier } \\
\text { A. thaliana }\end{array}$ & Gene name \\
\hline \multirow[t]{32}{*}{ Monoterpenoid } & XP_009416430 & AT1G60140 & $\begin{array}{l}\text { alpha, alpha-trehalose-phosphate } \\
\text { synthase [UDP-forming] } 7\end{array}$ \\
\hline & E3W9C4 & AT1G01180 & Alpha-humulene 10-hydroxylase; P450 mono-oxygenase \\
\hline & XP_009414014 & AT1G04920 & $\begin{array}{l}\text { alpha, alpha-trehalose-phosphate } \\
\text { synthase [UDP-forming] } 9\end{array}$ \\
\hline & XP_010930288 & AT5G16970 & 2-alkenal reductase $(N A D P(+)$-dependent)-like \\
\hline & XP_008791841 & AT1G26320 & 2-alkenal reductase $(N A D P(+)$-dependent)-like \\
\hline & EAZ26117 & AT1G09610 & hypothetical protein OsJ_09979 \\
\hline & XP_009409100 & AT1G49530 & $\begin{array}{l}\text { alpha, alpha-trehalose-phosphate synthase [UDP-forming] } \\
6 \text {-like }\end{array}$ \\
\hline & XP_009401137 & AT1G65560 & 2-alkenal reductase $(N A D P(+)$-dependent)-like \\
\hline & XP_009391422 & AT3G14530 & $\begin{array}{l}\text { alpha, alpha-trehalose-phosphate synthase [UDP-forming] } \\
\text { 6-like }\end{array}$ \\
\hline & AJD09824 & AT1G01290 & NADPH-dependent double-bond reductase 3 variant 2 \\
\hline & EYU33434 & AT1G11806 & hypothetical protein MIMGU_mgvla001209mg \\
\hline & CDP13064 & AT1G28620 & unnamed protein product \\
\hline & AGY49283 & AT1G31950 & chloroplast terpene synthase \\
\hline & XP_009390520 & AT1G06410 & $\begin{array}{l}\text { probable alpha, alpha-trehalose-phosphate synthase [UDP- } \\
\text { forming] } 9\end{array}$ \\
\hline & XP_009388531 & AT1G01190 & cytochrome P450 734A6-like \\
\hline & BAJ39894 & AT1G03410 & P450 mono-oxygenase \\
\hline & AAZ03640 & AT1G13150 & putative cytochrome $P 450$ \\
\hline & AJD09822 & AT1G09400 & NADPH-dependent double-bond reductase 2 \\
\hline & AJD09823 & AT1G12550 & NADPH-dependent double-bond reductase 3 variant 1 \\
\hline & XP_008238638 & AT1G11680 & 7-ethoxycoumarin O-deethylase-like \\
\hline & XP_009415178 & AT1G22410 & $\begin{array}{l}\text { probable alpha, alpha-trehalose-phosphate synthase [UDP- } \\
\text { forming] } 7\end{array}$ \\
\hline & XP_009413956 & AT1G01280 & cytochrome P450 98A2 \\
\hline & XP_009401244 & AT2G23800 & alpha, alpha-trehalose-phosphate synthase [UDP-forming] 5 \\
\hline & Q9SLN8 & AT1G77120 & $\begin{array}{l}\text { 2-alkenal reductase }(N A D P(+) \text {-dependent }) ; \text { Alkenal double } \\
\text { bound reductase; Allyl-alcohol dehydrogenase; Allylic alcohol } \\
\text { dehydrogenase } 1 ; \text { allyl-ADH1; Flavin-free double bond } \\
\text { reductase; NtDBR; Pulegone reductase; NtRed-1 }\end{array}$ \\
\hline & O48956 & AT1G12740 & Cytochrome P450 98A1 \\
\hline & $\mathrm{O} 23617$ & AT1G63970 & $\begin{array}{l}\text { Alpha, alpha-trehalose-phosphate synthase [UDP-forming] 5; } \\
\text { Trehalose-6-phosphate synthase 5; AtTPS5 }\end{array}$ \\
\hline & XP_009392100 & AT1G11600 & cytochrome P450 71A1-like \\
\hline & XP_009380769 & AT1G25083 & $\begin{array}{l}\text { probable alpha, alpha-trehalose-phosphate synthase [UDP- } \\
\text { forming] } 9\end{array}$ \\
\hline & XP_009409655 & AT1G11610 & cytochrome P450 71A1-like \\
\hline & XP_009391250 & AT1G24807 & $\begin{array}{l}\text { probable alpha, alpha-trehalose-phosphate synthase [UDP- } \\
\text { forming] } 9\end{array}$ \\
\hline & XP_009409766 & AT1G24909 & $\begin{array}{l}\text { probable alpha,alpha-trehalose-phosphate synthase [UDP- } \\
\text { forming] } 9\end{array}$ \\
\hline & Q94AH8 & AT3G14530 & $\begin{array}{l}\text { Alpha, alpha-trehalose-phosphate synthase [UDP-forming] 6; } \\
\text { Trehalose-6-phosphate synthase 6; AtTPS6 }\end{array}$ \\
\hline
\end{tabular}


Continued TABLE 2.

\begin{tabular}{|c|c|c|c|}
\hline $\begin{array}{c}\text { Metabolic biosynthetic } \\
\text { pathway }\end{array}$ & $\begin{array}{l}\text { Gene identifier } \\
\text { C.aeruginosa }\end{array}$ & $\begin{array}{c}\text { Gene identifier } \\
\text { A. thaliana }\end{array}$ & Gene name \\
\hline \multirow[t]{2}{*}{$\begin{array}{l}\text { Sesquiterpenoid } \\
\& \text { triterpenoid }\end{array}$} & P53800 & AT2G44520 & $\begin{array}{l}\text { Squalene synthase; SQS; SS; Full=FPP:FPP } \\
\text { farnesyltransferase; Farnesyl-diphosphate } \\
\text { farnesyltransferase }\end{array}$ \\
\hline & XP_009396917 & AT4G34640 & squalene synthase-like \\
\hline \multirow{4}{*}{$\begin{array}{l}\text { Terpenoid } \\
\& \text { steroid }\end{array}$} & P49293 & AT5G06130 & Phytoene synthase, chloroplastic; MEL5; Flags: Precursor \\
\hline & P37271 & AT1G01046 & phytoene synthase 2 , chloroplastic \\
\hline & XP_009386425 & AT5G61670 & phytoene synthase 2 , chloroplastic \\
\hline & P53797 & AT1G01183 & Phytoene synthase, chloroplastic; Flags: \\
\hline \multirow[t]{5}{*}{ Carotenoid } & XP_009399529 & AT5G05690 & cytochrome P450 724B1-like \\
\hline & P49293 & AT5G06130 & Phytoene synthase, chloroplastic; MEL5; Flags: Precursor \\
\hline & P53797 & AT1G01183 & Phytoene synthase, chloroplastic; Flags: \\
\hline & XP_009386425 & AT5G61670 & phytoene synthase 2 , chloroplastic \\
\hline & P37271 & AT1G01046 & Phytoene synthase, chloroplastic; Flags: \\
\hline \multirow[t]{5}{*}{ Diterpenoid } & XP_009388282 & AT2G19070 & benzyl alcohol O-benzoyltransferase \\
\hline & AFP33589 & AT1G62730 & phytoene synthase $2 a$ \\
\hline & XP_009399529 & AT5G05690 & cytochrome P450 724B1-like \\
\hline & Q6F4F5 & AT1G11680 & Cytochrome P450 724B1; Dwarf protein 11; OsDWARF11 \\
\hline & Q6F4F5 & AT1G11680 & Cytochrome P450 724B1; Dwarf protein 11; OsDWARF11 \\
\hline
\end{tabular}

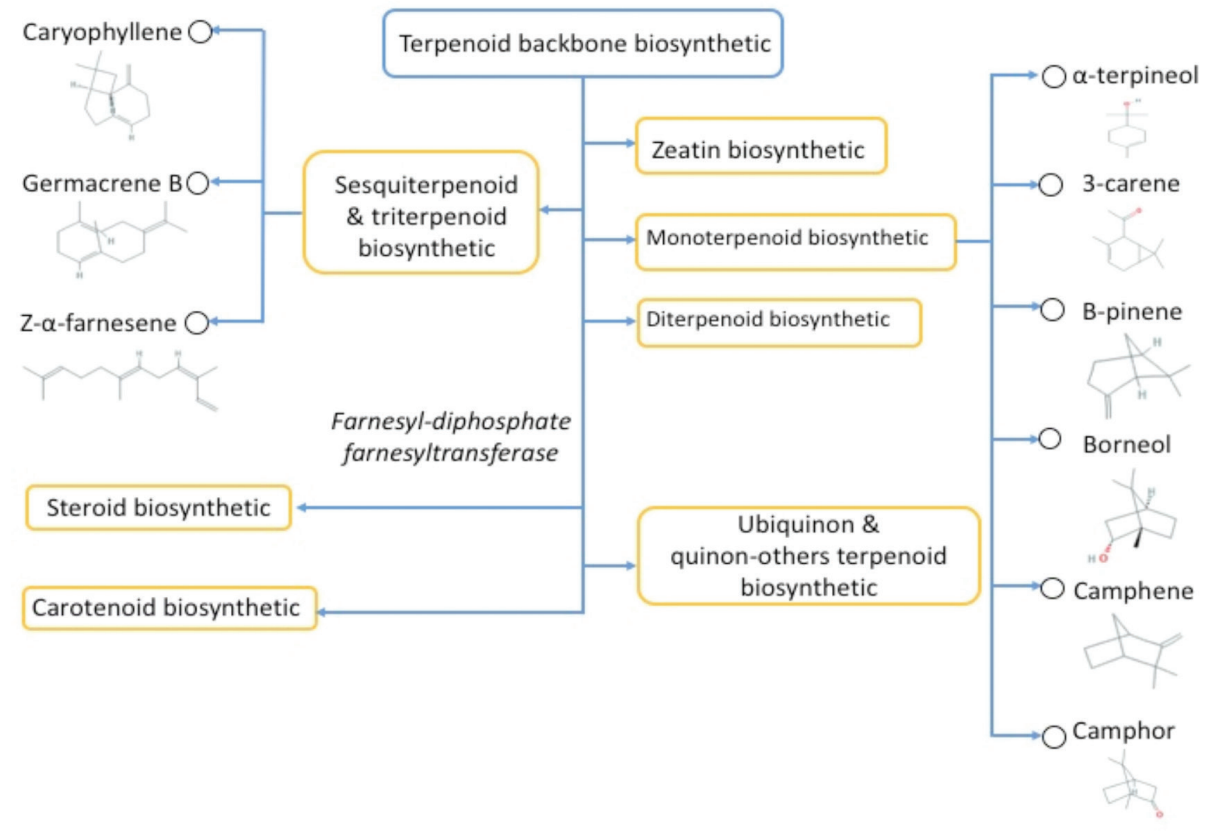

FIGURE 2. A reconstructed secondary metabolite biosynthetic pathway in the rhizome of $C$. aeruginosa. Yellow box refers to the biosynthetic pathway derived from the terpenoid backbone biosynthetic pathway. Nine potential metabolites and its structural chemistry were obtained from the metabolites profiles of $C$. aeruginosa rhizome

biosynthetic pathways in the production of potential metabolites with interesting pharmacological activities such as anti-tumor, anti-inflammatory, antimicrobial and antioxidant activity. This study has showed a putative pathway of $C$. aeruginosa rhizome constructed based on the interaction between genes and metabolites. This finding can be used to facilitate a better understanding on the biological mechanism of the secondary metabolite 
production in $C$. aeruginosa rhizome. This will provide a valuable knowledge in search for potential materials with therapeutic values towards the development of health product based on local medicinal herbs.

\section{ACKNOWLEDGEMENTS}

This work was supported by P-RB250-1001-2015 awarded to AZ from MARDI Mega project RMK-10.

\section{REFERENCES}

Abe, I., Rohmer, M. \& Prestwich, G.D. 1993. Enzymatic cyclization of squalene and oxidosqualene to sterols and triterpenes. Chemical Reviews 93(6): 2189-2206.

Bateman, A., Martin, M.J., O’Donovan, C., Magrane, M., Apweiler, R., Alpi, E., Antunes, R., Arganiska, J., Bely, B., Bingley, M., Bonilla, C., Britto, R., Bursteinas, B., Chavali, G., Cibrian-Uhalte, E., Da Silva, A., De Giorgi, M., Dogan, T., Fazzini, F., Gane, P., Castro, L.G., Garmiri, P., HattonEllis, E., Hieta, R., Huntley, R., Legge, D., Liu, W., Luo, J., Macdougall, A., Mutowo, P., Nightingale, A., Orchard, S., Pichler, K., Poggioli, D., Pundir, S., Pureza, L., Qi, G., Rosanoff, S., Saidi, R., Sawford, T., Shypitsyna, A., Turner, E., Volynkin, V., Wardell, T., Watkins, X., Zellner, H., Cowley, A., Figueira, L., Li, W., McWilliam, H., Lopez, R., Xenarios, I., Bougueleret, L., Bridge, A., Poux, S., Redaschi, N., Aimo, L., Argoud-Puy, G., Auchincloss, A., Axelsen, K., Bansal, P., Baratin, D., Blatter, M.C., Boeckmann, B., Bolleman, J., Boutet, E., Breuza, L., Casal-Casas, C., De Castro, E., Coudert, E., Cuche, B., Doche, M., Dornevil, D., Duvaud, S., Estreicher, A., Famiglietti, L., Feuermann, M., Gasteiger, E., Gehant, S., Gerritsen, V., Gos, A., Gruaz-Gumowski, N., Hinz, U., Hulo, C., Jungo, F., Keller, G., Lara, V., Lemercier, P., Lieberherr, D., Lombardot, T., Martin, X., Masson, P., Morgat, A., Neto, T., Nouspikel, N., Paesano, S., Pedruzzi, I., Pilbout, S., Pozzato, M., Pruess, M., Rivoire, C., Roechert, B., Schneider, M., Sigrist, C., Sonesson, K., Staehli, S., Stutz, A., Sundaram, S., Tognolli, M., Verbregue, L., Veuthey, A.L., Wu, C.H., Arighi, C.N., Arminski, L., Chen, C., Chen, Y., Garavelli, J.S., Huang, H., Laiho, K., McGarvey, P., Natale, D.A., Suzek, B.E., Vinayaka, C.R., Wang, Q., Wang, Y., Yeh, L.S., Yerramalla, M.S. \& Zhang, J. 2015. UniProt: A hub for protein information. Nucleic Acids Research 43: 204-212.

Berardini, T.Z., Reiser, L., Li, D., Mezheritsky, Y., Muller, R., Strait, E. \& Huala, E. 2015. The Arabidopsis information resource: Making and mining the "gold standard" annotated reference plant genome. Genesis 53(8): 474-485.

Cameron, S.I., Smith, R.F. \& Kierstead, K.E. 2005. Linking medicinal/nutraceutical products research with commercialization. Pharmaceutical Biology 43(5): 425-433.

Cavill, R., Jennen, D., Kleinjans, J. \& Briedé, J.J. 2015. Transcriptomic and metabolomic data integration. Briefings in Bioinformatics 17(5): 891-901.

Chatr-Aryamontri, A., Oughtred, R., Boucher, L., Rust, J., Chang, C., Kolas, N.K., O’Donnell, L., Oster, S., Theesfeld, C., Sellam, A., Stark, C., Breitkreutz, B.J., Dolinski, K. \& Tyers, M. 2017. The BioGRID interaction database: 2017 update. Nucleic Acids Research 45: 369-379.

Filippis, L.F.D. 2016. Plant secondary metabolites: From molecular biology to health products. In Plant-Environment Interaction: Responses and Approaches to Mitigate Stress, edited by Azooz, M.M. \& Ahmad, P. New Jersey: WileyBlackwell. pp. 263-300.

Francke, C., Siezen, R.J. \& Teusink, B. 2005. Reconstructing the metabolic network of a bacterium from its genome. Trends in Microbiology 13(11): 550-558.

Hastings, J., De Matos, P., Dekker, A., Ennis, M., Harsha, B., Kale, N., Muthukrishnan, V., Owen, G., Turner, S., Williams, M. \& Steinbeck, C. 2013. The ChEBI reference database and ontology for biologically relevant chemistry: Enhancements for 2013. Nucleic Acids Research 41: 456-463.

Kamazeri, T.S.A.T., Samah, O.A., Taher, M., Susanti, D. \& Qaralleh, H. 2012. Antimicrobial activity and essential oils of Curcuma aeruginosa, Curcuma mangga and Zingiber cassumunar from Malaysia. Asian Pacific Journal of Tropical Medicine 5(3): 202-209.

Kanehisa, M., Sato, Y., Kawashima, M., Furumichi, M.\& Tanabe, M. 2016. KEGG as a reference resource for gene and protein annotation. Nucleic Acids Research 44: 457-462.

de Las Rivas, J. \& Fontanillo, C. 2010. Protein-protein interactions essentials: Key concepts to building and analyzing interactome networks. PLoS Computational Biology 6(6): 1-8.

de Oliveira Dal'Molin, C.G., Orellana, C., Gebbie, L., Steen, J., Hodson, M.P., Chrysanthopoulos, P., Plan, M.R., McQualter, R., Palfreyman, R.W. \& Nielsen, L.K. 2016. Metabolic reconstruction of Setaria italica: A systems biology approach for integrating tissue-specific omics and pathway analysis of bioenergy grasses. Frontiers in Plant Science 7: 1-18.

Kitano, H. 2002. Computational systems biology. Nature 420: 206-210.

Lee, M.H., Jeong, J.H., Seo, J.W., Shin, C.G., Kim, Y.S., In, J.G., Yang, D.C., Yi, J.S. \& Choi, Y.E. 2004. Enhanced triterpene and phytosterol biosynthesis in Panax ginseng overexpressing squalene synthase gene. Plant and Cell Physiology 45(8): 976-984.

Li, S., Li, Y. \& Smolke, C.D. 2018. Strategies for microbial synthesis of high-value phytochemicals. Nature Chemistry 10(4): 395-404.

Liu, Y., Roy, S.S., Nebie, R.H.C., Zhang, Y. \& Nair, M.G. 2013. Functional food quality of Curcuma caesia, Curcuma zedoaria and Curcuma aeruginosa endemic to Northeastern India. Plant Foods for Human Nutrition 68: 72-77.

Matsuba, Y., Zi, J., Jones, A.D., Peters, R.J. \& Pichersky, E. 2015. Biosynthesis of the diterpenoid lycosantalonol via nerylneryl diphosphate in Solanum lycopersicum. PLoS ONE 10(3): 1-16.

Othman, R., Mohd Zaifuddin, F.A. \& Hassan, N.M. 2014. Carotenoid biosynthesis regulatory mechanisms in plants. Journal of Oleo Science 63(8): 753-760.

Rajkumari, S. \& Sanatombi, K. 2018. Nutritional value, phytochemical composition, and biological activities of edible Curcuma species: A review. International Journal of Food Properties 20(3): 2668-2687.

Saithong, T., Rongsirikul, O., Kalapanulak, S., Chiewchankaset, P., Siriwat, W., Netrphan, S., Suksangpanomrung, M., Meechai,A.\& Cheevadhanarak, S. 2013. Starch biosynthesis in cassava: A genome-based pathway reconstruction and its exploitation in data integration. BMC Systems Biology 7: 1-18.

Sanchez, S. \& Demain, A.L. 2008. Metabolic regulation and overproduction of primary metabolites. Microbial Biotechnology 1(4): 283-319. 
Sawai, S. \& Saito, K. 2011. Triterpenoid biosynthesis and engineering in plants. Frontiers in Plant Science 2: 1-8.

Schläpfer, P., Zhang, P., Wang, C., Kim, T., Banf, M., Chae, L., Dreher, K., Chavali, A.K., Nilo-Poyanco, R., Bernard, T., Kahn, D. \& Rhee, S.Y. 2017. Genome-wide prediction of metabolic enzymes, pathways, and gene clusters in plants. Plant Physiology 173(4): 2041-2059.

Seaver, S.M.D., Henry, C.S. \& Hanson, A.D. 2012. Frontiers in metabolic reconstruction and modeling of plant genomes. Journal of Experimental Botany 63(6): 2247-2258.

Simoh, S. \& Zainal, A. 2015. Chemical profiling of Curcuma aeruginosa Roxb. rhizome using different techniques of solvent extraction. Asian Pacific Journal of Tropical Biomedicine 5(5): 412-417.

Singh, B. \& Sharma, R.A. 2015. Plant terpenes: Defense responses, phylogenetic analysis, regulation and clinical applications. 3 Biotech 5: 129-151.

Szklarczyk, D., Morris, J.H., Cook, H., Kuhn, M., Wyder, S., Simonovic, M., Santos, A., Doncheva, N.T., Roth, A., Bork, P., Jensen, L.J. \& Von Mering, C. 2017. The STRING database in 2017: Quality-controlled protein-protein association networks, made broadly accessible. Nucleic Acids Research 45: 362-368.

Vishwakarma, R.K., Patel, K., Sonawane, P., Kumari, U., Singh, S., Ruby, Abbassi, S., Agrawal, D.C., Tsay, H.S. \& Khan, B.M. 2015. Squalene synthase gene from medicinal herb Bacopa monniera: Molecular characterization, differential expression, comparative modeling and docking studies. Plant Molecular Biology Reporter 33(6): 1675-1685.

Wurtele, E.S., Chappell, J., Daniel Jones, A., Celiz, M.D., Ransom, N., Hur, M., Rizshsky, L., Crispin, M., Dixon, P., Liu, J., Widrlechner, M.P. \& Nikolau, B.J. 2012. Medicinal plants: A public resource for metabolomics and hypothesis development. Metabolites 2(4): 1032-1059.
Zaidan, M.W.A., Zainal, A., Jaganath, I.B. \& Simoh, S 2016. Transcriptomics and metabolomics data integration for identification the metabolic pathways in Curcuma aeruginosa. Proceedings of the International Conference on Natural Products 2016. Terengganu. p. 1.

Nurul-Syafika Mohamad-Fauzi \& Zeti-Azura MohamedHussein*

Centre for Frontier Sciences

Faculty of Science and Technology

43600 UKM Bangi, Selangor Darul Ehsan

Malaysia

Rabiatul-Adawiah Zainal-Abidin \& Zeti-Azura MohamedHussein*

Centre for Bioinformatics Research Institute of Systems Biology (INBIOSIS)

Universiti Kebangsaan Malaysia 43600 UKM Bangi, Selangor Darul Ehsan

Malaysia

Mohd Waznul Adly Zaidan, Sanimah Simoh \& Alizah Zainal Institut Penyelidikan dan Kemajuan Pertanian Malaysia (MARDI) 43300 Serdang, Selangor Selangor Darul Ehsan Malaysia

*Corresponding author; email: zeti.hussein@ukm.edu.my

Received: 30 May 2018

Accepted: 19 September 2018 